\title{
Effect of irrigation at critical stages on the phenology of flowering and fruiting of the cactus Opuntia spp.
}

\author{
M. Arba ${ }^{a *}$, A. Falisse ${ }^{b, c}$, R. Choukr-Allah ${ }^{a}$ and M. Sindic ${ }^{d}$ \\ aPlant ecophysiology unit, Department of Horticulture, Hassan II Institute of Agronomy and Veterinary Medicine, \\ Horticultural Complex of Agadir, Morocco \\ ${ }^{\mathrm{b} C r o p}$ Production Unit, Gembloux Agro-Bio Tech, University of Liège, Liège, Belgium \\ ${ }^{c}$ Faculty of Agriculture, University of Agricultural Sciences and Veterinary Medicine, Cluj, Romania \\ ${ }^{\mathrm{d}}$ Laboratory of Food Quality and Safety, Gembloux Agro Bio Tech, University of Liège, Liège, Belgium \\ *e-mail: arbamohamed@yahoo.fr
}

Received: October 3, 2016 - Accepted: May 10, 2017 - Distributed: November 30, 2018

(With 2 figures)

\begin{abstract}
This paper briefly reports some effects of irrigations at two critical periods on the phenology of three varieties of cactus pear cultivated in Agadir area: the spineless varieties 'Aissa' and 'Moussa' and the thorny one 'Achefri'. In the first year experiments (2010-2011) treatments of irrigation used were: (T1) $0 \mathrm{~mm}$, (T2) $30 \mathrm{~mm}$ during flowering and $30 \mathrm{~mm}$ during fruit enlargement and (T3) $30 \mathrm{~mm}$ only during fruit enlargement. In the $2^{\text {nd }}$ year experiments, irrigation treatments were: (T1) $0 \mathrm{~mm}$, (T2) $60 \mathrm{~mm}$ during flowering and $60 \mathrm{~mm}$ during fruit enlargement and (T3) $60 \mathrm{~mm}$ only during fruit enlargement. Treatments of irrigation were applied between mid-April and mid-June in the $1^{\text {st }}$ year experiments and in February and May in the $2^{\text {nd }}$ year experiments. Results of the first year experiments showed that the emission of buds was higher in the thorny variety than in the spineless ones (more than 6 emitted buds/cladode $v s$ less than 4.5 in the spineless varieties). In the second year, irrigation increased the emission of buds in the three varieties (more than 7 emitted buds/cladode for each T2 and T3 of all varieties vs not more than 5 for T1) and the duration of the flowering phase of these varieties. However, irrigation did not modify the proportions of fruits reaching commercial maturity during the early or the late period of maturation.
\end{abstract}

Keywords: Opuntia, cactus pear, bud emission, flowering, fruiting.

\section{Efeito da irrigação em estágios críticos sobre a fenologia de floração e frutificação do cacto Opuntia spp.}

\section{Resumo}

Este artigo relatou brevemente alguns efeitos das irrigações em dois períodos críticos na fenologia de três variedades de Opuntia cultivadas na área de Agadir: as variedades sem espinhos 'Aissa' e 'Moussa' e um espinhoso 'Achefri'. No primeiro ano (2010-2011) os seguintes tratamentos do experimento da irrigação foram usados: (T1) 0 milímetros, (T2) 30 milímetros durante a florescência e 30 milímetros durante a ampliação do fruto e (T3) 30 milímetros somente durante a ampliação do fruto. No segundo ano das experiências, os tratamentos da irrigação foram: (T1, 0 milímetros), (T2) 60 milímetros durante a florescência e 60 milímetros durante a ampliação do fruto e (T3) 60 milímetros somente durante a ampliação do fruto. Os tratamentos da irrigação foram aplicados entre a metade de abril e metade de junho nas experiências do primeira ano e em fevereiro e maio nas experiências do segundo ano. Os resultados das experiências do primeiro ano mostraram que a emissão de brotos foi maior na variedade espinhosa do que no rufia (mais de 6 emitida gomos/cladode vs inferior a 4,5 no rufia variedades). No segundo ano, a irrigação aumentou a emissão dos botões nas três variedades (mais de 7 botões emitidos/cladÓdio para cada T2 e T3 de todas as variedades não mais que 5 para o T1) e a duração da fase de florescência destas variedades. Contudo, a irrigação não alterou as proporções de frutos que alcançaram a maturidade comercial durante o período adiantado ou atrasado de maturação.

Palavras-chave: Opuntia, palma, emissão do botão, florescência, frutificação.

\section{Introduction}

The cactus Opuntia plays an important role in the systems of agriculture of arid and semi-arid regions thanks to its efficient use of water (Nobel and Bobich,
2002; Nobel, 2002; Oliveira et al., 2007; Sales et al., 2009; Silva et al., 2014) and its multitude of uses (fodder, human consumption, protection against erosion, etc.) and 
products (edible fruits, young cladodes as vegetable, adult cladodes as fodder, oil from seeds, etc.) (Nefzaoui and Ben Salem, 2000; Le Houérou, 2002; Felker and Inglese, 2003; Oliveira et al., 2007; Arba, 2009; Inglese, 2010; Silva et al., 2014). It is one of the main factors that ensure the food security to rural families, the creation of job opportunities, and income in the Brazilian semi arid region. Cactus pear constitutes a potential food source for animals in this region (Ramos et al., 2015). Its drought resistance and efficient use of water make the cactus rarely irrigated (Nobel, 2002). However, currently, the irrigation of cactus pear is a common practice in hot and dry summer areas where cultivation for commercial production is practiced (Mexico, USA, Chile, Italy, South Africa, Brazil, Morocco, etc.) (Dubeux Junior et al., 2006; Inglese, 2010). A continuous irrigation of plants involved an important emission of floral buds in spring (Nerd and Mizrahi, 2010) and the beneficial effect of water (whether of rain or irrigation) on the emission of vegetative and floral buds was shown by several authors (Mulas and D'Hallewin, 1997; Inglese, 2010; Nerd and Mizrahi, 2010). Recently, plantations with high plant density and drip irrigation system are also developed in Southern Morocco, mainly in the areas of Haouz and Guelmim.

In the Mediterranean region, the principal flush of buds occurs in spring (March-April) when temperatures are favorable and day length increase. Flowers are often emitted on one year old cladodes, whereas shoots are mainly emitted on two or more years old cladodes (Pimienta-Barrios and Del Castillo, 2002; Reyes-Agüero et al., 2006; Nerd and Mizrahi, 2010). After the emission of floral buds, flowering takes place for about one month and is followed by the development of fruits. The plant is able to flower a second time during the same year if the environmental conditions are favorable (i.e. clement temperatures, frequent fogs or high hygrometry of the air) or through the use of advanced agriculture techniques such as continuous irrigation and fertilization programs, or irrigation during the dry summer period (Pimienta-Barrios and Del Castillo, 2002; Reyes-Agüero et al., 2006; Segantini et al., 2010; FAO, 2013). This phenomenon called "reflowering" presents a non-negligible interest to the growers by increasing total annual production and modifying the timing of the production both resulting in higher income. The plant starts producing fruits 2-3 years after plantation. Full production is obtained approximately 7 years after plantation, and fruit production can last 25-30 years or longer (Pimienta-Barrios and Del Castillo, 2002; Reyes-Agüero et al., 2006; Nerd and Mizrahi, 2010).

The duration of the floral buds emission phase in Opuntia ficus-indica (L.) Mill. vary from 3-5 weeks (PimientaBarrios and Del Castillo, 2002; Reyes-Agüero et al., 2005) to two months (Segantini et al., 2010), but can exceed 25 weeks in some species (Pimienta-Barrios and Del Castillo, 2002; Reyes-Agüero et al., 2005). The period of time between the differentiation of floral buds and flowering is relatively short in cactus pears (30 to 50 days) (Pimienta-Barrios and Del Castillo, 2002; Segantini et al., 2010) and the period between the emission of floral buds and flowering vary from 7 weeks (Pimienta-Barrios and Del Castillo, 2002; Nerd and Mizrahi, 2010) to two months and half (Reyes-Agüero et al., 2005). Flowering extends over a period of 48 days (Segantini et al., 2010) to 100 days (Pimienta-Barrios and Del Castillo, 2002; Reyes-Agüero et al., 2006; Nerd and Mizrahi, 2010; Lenzi and Orth, 2012) and the peak of flowering corresponds to the period when $50 \%$ of flowers are open (Segantini et al., 2010). Several authors indicated that flowering in cactus pear is not synchronous: in parallel with the floral buds emission and formation, flowers are at the first stage of differentiation, others are in flowering and fruit growth is simultaneously occurring (Pimienta-Barrios and Del Castillo, 2002; Reyes-Agüero et al., 2006; Segantini et al., 2010). The consequence of this is that the phases of flowering and fruit maturation are spread out over a period of several weeks (Reyes-Agüero et al., 2006; Nerd and Mizrahi, 2010). Barbara (2007) determined the duration of a phenological phase of flowering or fruiting as period which extends from the week when the characters of this phase are visible on a variety until the last week when these characters are visible on this variety. Thus, the period of flowering for example extends from the week when open flowers are visible on a variety until the last week when the open flowers are visible on this variety.

The fruit development period (FDP) is defined as the period of time between the formation of floral buds (or reproductive bud break) and the maturation of fruits (or 50\% of fruit ripening) (Barbara, 2007). Floral buds are formed when they reach a length of 4-5 mm; at this stage they become spherical and easy to distinguish from vegetative buds, which are punt-shaped. This is also the stage where the first signs of flower structure can be detected under a microscope (Pimienta-Barrios and Del Castillo, 2002; Reyes-Agüero et al., 2006; Barbara, 2007; Nerd and Mizrahi, 2010). There is a large variability in the FDP, which appears to be variety-specific (Barbara, 2007; Nerd and Mizrahi, 2010); it also varies between regions, as it depends on the climatic conditions of the cultivation medium (Nerd and Mizrahi, 2010; Segantini et al., 2010). The FDP for the majority of varieties studied in South Africa is 120-130 days; for plants which have an earlier emission of floral buds, the FDP is longer and can reach up to 148 days (Barbara, 2007). Other authors reported that the FDP (from the emission of floral buds until fruit maturation) varies from 96 days (Segantini et al., 2010) to about 122 days (Nerd and Mizrahi, 2010). The fruit maturation occurs 66 days (Segantini et al., 2010) to 80-90 days (Nerd and Mizrahi, 2010) after flowering. It extends over a period of 80 days (Segantini et al., 2010) to several weeks (Nerd and Mizrahi, 2010) and the peak of maturation corresponds to the period when $50 \%$ of fruits are at maturity (Segantini et al., 2010).

Results on the impact of irrigation on fruit yield and quality of the cactus Opuntia (Arba et al., 2016) showed in the first year experiments (2010-2011) a significant positive effect of irrigation on fruit yield of the thorny variety and no effect on the spineless varieties. Fruit weight and size 
(length and diameter) were not affected by irrigation. In the second year experiments (2011-2012), irrigations had significant positive effects on fruit yield and quality of the three varieties and no effect on the biochemical quality of fruits, the treatment $\mathrm{T} 3$ with a single irrigation at fruit enlargement giving the best results.

From the same experiments, our goal was to see whether in addition to fruit yield and quality, the irrigation could modify the phenology of plants, in particular the dates of the first maturations of fruits and those of the last maturations. We understand the interest of the prolongation of the maturation period / harvesting period or to move it - either in precocity, or in tardivity - allowing marketing fruits in "out of season" periods when the prices are higher.

\section{Material and Methods}

To meet these aims, we carried out for two years in the Agadir area a precise monitoring of the phenology of plants in trials having as other objectives to record the effects of irrigations on fruit yield and quality of three varieties of cactus pear: the spineless 'Aissa' and 'Moussa' of O. ficus-indica and the thorny 'Achefri' of $O$. megacantha Salm Dyck (see Figure 1). The experimental design was a split-plot with four replications, the factor variety constituting the large plots and the factor irrigation the small ones. A drip irrigation system has been used in order to well control the amounts of irrigation water.

In the first year of experiment, irrigation treatments were as follow: T1: $0 \mathrm{~mm}$ (control without irrigation); $\mathrm{T} 2: 30 \mathrm{~mm}$ during flowering (mid-April) and $30 \mathrm{~mm}$ during fruit enlargement (mid-June); and T3: $30 \mathrm{~mm}$ only during fruit enlargement. In the second year experiments, treatments of irrigation used were: (T1) $0 \mathrm{~mm}$, (T2) $60 \mathrm{~mm}$ during flowering (February) and $60 \mathrm{~mm}$ during fruit enlargement (May) and (T3) $60 \mathrm{~mm}$ only on fruit enlargement. The frequency of water applications in $\mathrm{T} 2$ and $\mathrm{T} 3$ treatments of the first year and second year experiments was for 1 every 3 days and the dose of water in each application was $4 \mathrm{~mm}$ in the $1^{\text {st }}$ year and $8 \mathrm{~mm}$ in the $2^{\text {nd }}$ year.

In the first year, T2: application of two sequences of $30 \mathrm{~mm}$, the first one in April-May (from 18/04 to 19/05: 7 times $4 \mathrm{~mm}$ every $3 \mathrm{~d}$ day then once of $2 \mathrm{~mm}$ ), the second in May-June (from May $24^{\text {th }}$ to June $15^{\text {th }}$ ), that means $60 \mathrm{~mm}$ in total; T3: application of the second sequence only with $30 \mathrm{~mm}$ in May-June.

In the second year, T2: application of two sequences of $60 \mathrm{~mm}$, the first in February, 7 times $8 \mathrm{~mm}$ every $3^{\text {rd }}$ day and once of $4 \mathrm{~mm}$ (from $1^{\text {st }}$ February to $1^{\text {st }}$ March); the second in May (from the $1^{\text {st }}$ May to May 30); T3: application of the second sequence only for $60 \mathrm{~mm}$ in May.

Climatic data, in particular the rainfall and temperature data (see Figure 2), have been recorded in Saouda station located at $10 \mathrm{~km}$ from the site of trials. It has been considered that the vegetation annual cycle started after the last fruits maturation of the previous cycle, which under the local climatic conditions corresponds to October $1^{\text {st }}$.

For this phenological study, flowering and fruiting of the plants were observed since the emission of vegetative and floral buds until the fruit maturation. In each experimental unit, observations (such as the date of the first appearance of a stage) and the enumerations

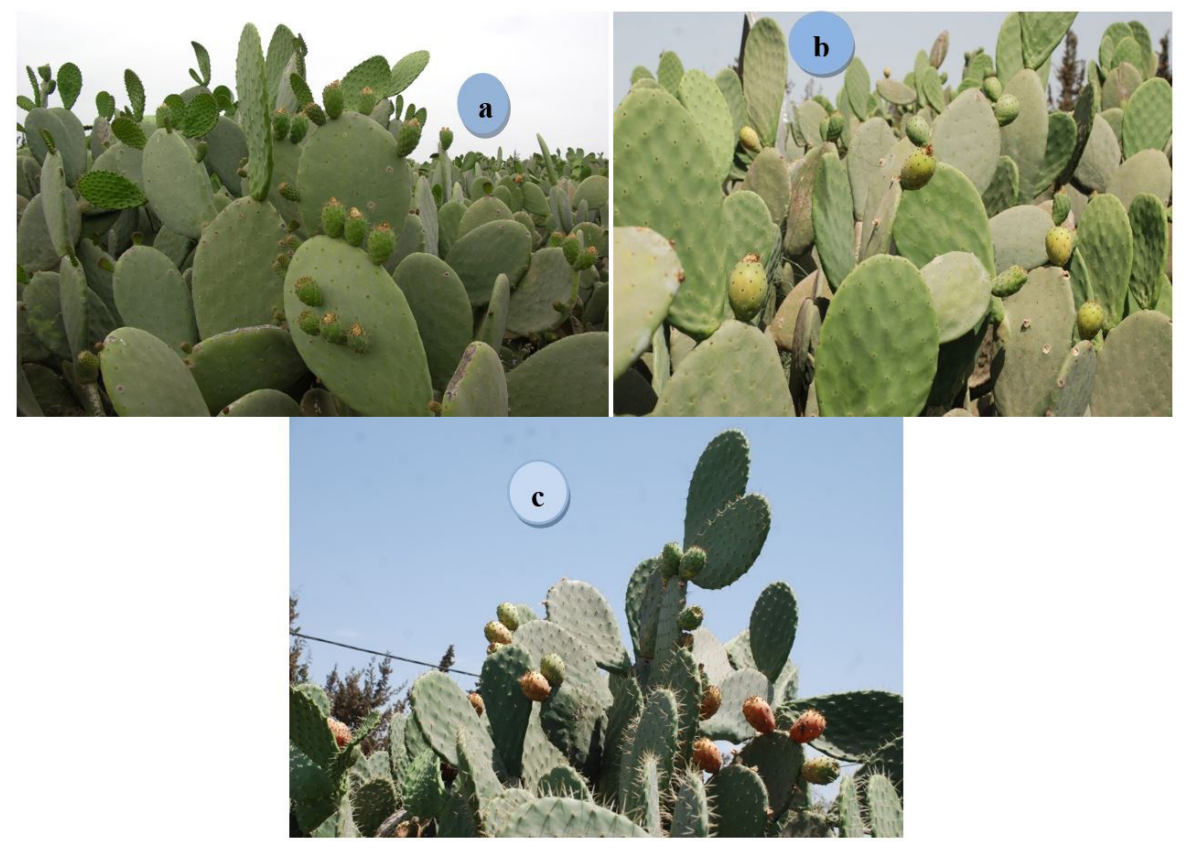

Figure 1. Varieties used in the study: the spineless varieties 'Aissa' (a) and 'Moussa' (b) and the thorny one 'Achefri' (c): pictures were taken during the ripening phase in July 2011 and show differences in spines and cladode colour (green for the spineless cultivars and glaucous for the thorny cultivar). 


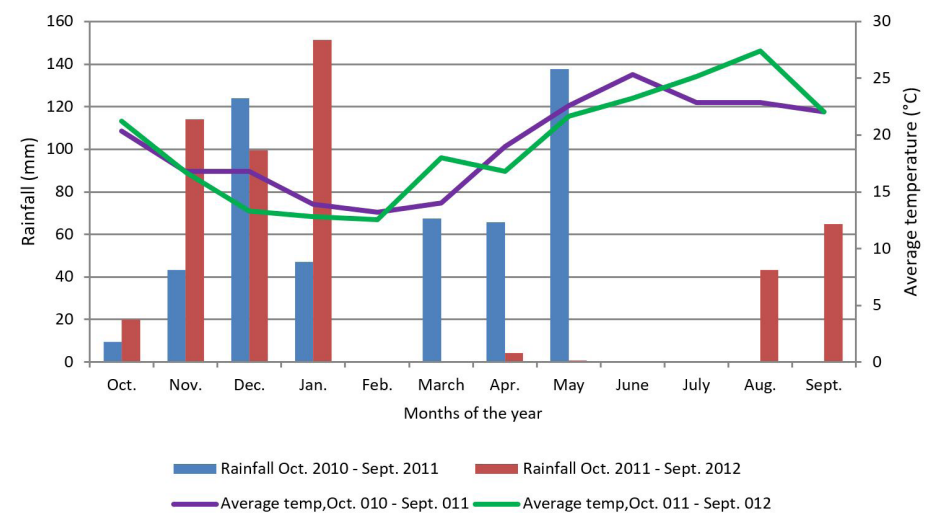

Figure 2. Climatic conditions of the area of experiments (rainfall and average temperature) during the two years of study.

(like the number of flowers) were realized on a sample of 10 one year old cladodes: on five plants, two cladodes per plant were marked and numbered from 1 to 10 in the beginning of season. Observations were carried out on a total of 360 cladodes.

Observations and enumerations were carried out in a rate of about a week to ten days. They started in March in the first year and February in the second year (either in dates which made it possible to follow the emission of buds). They finished at the end of the cycle, in September, by the enumeration of the last fruits having reached maturity during the previous week. Observations are related to the start and end period of the emission of buds, the flowering, the fruit development and the fruits maturation. On a same plant or even on a same cladode, the phases delimited by these stages overlap.

We considered as the start date (or the end date) of a phase the date of observation when the start or the end stage of this phase is reached on at least one of the ten selected cladodes in one replication of an irrigation treatment. The starting and end dates of a phase were determined according to visual observations of this phase, by considering the average date of appearance of this phase on the 4 replicates of a treatment of irrigation during the starting or the end week of appearance of this phase in this treatment.

The collected data have been summarized and analyzed by means and standard errors, or when relevant, by ANOVA in order to detect possible "varieties $\times$ irrigations" interactions and to examine the magnitudes of irrigation effects and their level of significancy. Used tools have been MINITAB.

\section{Results and Discussion}

\subsection{In the first year of the study}

For the emission and formation of floral buds, irrigation was not taken in consideration because it coincided with rains in March-May (see Figure 2).

The duration of the phase of the emission of vegetative and floral buds has been 89 days long at the spineless varieties 'Aissa' and 'Moussa' and 74 days for the thorny variety 'Achefri' and the duration of the phase of the formation of floral buds was 90 days long at the spineless varieties and 76 days for the thorny one (as shown in Table 1). The peak of the emission and formation of floral buds for all varieties is located at the end of March-the beginning of April and the importance of the emission and formation of buds in this period is due to favorable climatic conditions (rainfall, increase in temperatures and day length). The number of emitted and formed buds was higher in the thorny variety than in the spineless ones (more than 6 formed buds /cladode $v s$ not more than 4.5 in the spineless varieties) and the difference is significant between varieties $(p<0.05)$ (as shown in Table 2 ).

The duration of the phase of flowering at the spineless varieties was 81 to 89 days long for the three treatments of irrigation. For the variety 'Achefri' the duration of the phase of flowering was 65 days long in T1 not irrigated and significantly longer (81 days) in the irrigated treatments (as shown in Table 1). The flowering peak for the all varieties and treatments of irrigation is located in April. Irrigation had no effect neither on flowering, nor on the duration of the flowering phase of the spineless varieties. It has a significant positive effect of about 16 days on the duration of flowering of the thorny variety, this increase resulting from about 8 days for each of precocity and lateness.

The duration of the maturation phase in not irrigated plants of 'Aissa' and 'Moussa' (79 and 72 days respectively), is prolonged to 89 days after the application of T3 treatment. For 'Achefri', irrigations have elongated the maturation phase by two weeks (from 62 to 79 days) (as shown in Table 1). Irrigation had no effect on the maturation peak of all varieties. It had a significant positive effect on the duration of the maturation phase of the varieties 'Moussa' and 'Achefri'.

The FDP of all varieties under the three treatments of irrigation varies between 146 and 165 days. Irrigation had no effect on the FDP of the three varieties and the variability in FDP between varieties is due to differences regarding the dates of formation of floral buds and of fruit maturation. The FDP of the three varieties is longer than the FDP of the majority of varieties in South Africa (120-130 days) (Barbara, 2007) and than those reported for some Mediterranean countries (122 days in Italy) (Nerd and Mizrahi, 2010). The FDP of these varieties is similar or a little longer than that of varieties with an earlier emission of floral buds in South Africa (148 days) (Barbara, 2007). 


\subsection{In the second year of the study}

For the spineless varieties 'Aissa' and 'Moussa', the duration of the floral buds formation phase has been 83-98 days long in the three treatments of irrigation. For 'Achefri' the duration of this phase was 76-83 days long in all treatments of irrigation (as shown in Table 3).
The appearance dates of the first floral buds are located between the end of January for 'Aissa' and 'Moussa' and the beginning of February for 'Achefri'. The emission peak of buds was located in March for the all varieties and treatments of irrigation. The number of emitted buds was often higher in irrigated treatments (it can reach more

Table 1. Durations and start and end dates of the phases of flowering and fruit maturation of the varieties 'Achefri', 'Aissa' and 'Moussa' under the treatments of irrigation T1, T2 and T3, year 2011.

\begin{tabular}{|c|c|c|c|c|}
\hline & \multicolumn{2}{|c|}{ Phase of Flowering } & \multicolumn{2}{|c|}{ Phase of Fruit maturation } \\
\hline & duration (days) & Start and end dates & duration (days) & Start and end dates \\
\hline \multicolumn{5}{|c|}{ 'Aïssa' } \\
\hline $\mathrm{T} 1(0 \mathrm{~mm})$ & 89 & $03 / 03-01 / 06$ & 79 & $28 / 06-15 / 09$ \\
\hline $\mathrm{T} 2(30+30 \mathrm{~mm})$ & 81 & $11 / 03-01 / 06$ & 79 & $28 / 06-15 / 09$ \\
\hline $\mathrm{T} 3(0+30 \mathrm{~mm})$ & 82 & $03 / 03-25 / 05$ & 89 & $18 / 06-15 / 09$ \\
\hline \multicolumn{5}{|c|}{ 'Moussa' } \\
\hline $\mathrm{T} 1(0 \mathrm{~mm})$ & 81 & $11 / 03-01 / 06$ & 72 & $28 / 06-08 / 09$ \\
\hline $\mathrm{T} 2(30+30 \mathrm{~mm})$ & 81 & $11 / 03-01 / 06$ & 79 & $28 / 06-15 / 09$ \\
\hline $\mathrm{T} 3(0+30 \mathrm{~mm})$ & 89 & 03/03-01/06 & 89 & $18 / 06-15 / 09$ \\
\hline \multicolumn{5}{|c|}{ 'Achefri' } \\
\hline $\mathrm{T} 1(0 \mathrm{~mm})$ & 65 & $21 / 03-25 / 05$ & 62 & $07 / 07-08 / 09$ \\
\hline $\mathrm{T} 2(30+30 \mathrm{~mm})$ & 81 & $11 / 03-01 / 06$ & 79 & $28 / 06-15 / 09$ \\
\hline $\mathrm{T} 3(0+30 \mathrm{~mm})$ & 81 & $11 / 03-01 / 06$ & 79 & 28/06-15/09 \\
\hline
\end{tabular}

Table 2. Vegetative and floral buds emission at the three varieties 'Achefri', 'Aissa' and 'Moussa' and under the three treatments of irrigation T1, T2 and T3 in 2011 (irrigations coincided with rains in march-May).

\begin{tabular}{lccc}
\hline \multicolumn{1}{c}{$\begin{array}{c}\text { Treatment of } \\
\text { irrigation }\end{array}$} & Achefri & Varieties & Moussa \\
\cline { 2 - 3 } & Number of emitted buds by cladode in March & 5.50 \\
\hline T1 $(0 \mathrm{~mm})$ & 7.00 & 3.50 & 4.50 \\
T2 $(60+60 \mathrm{~mm})$ & 6.50 & 3.25 & 3.50 \\
T3 $(0+60 \mathrm{~mm})$ & 5.25 & 4.00 & $4.50 a$ \\
Mean & $6.25 b$ & $3.58 a$ & $\mathrm{~ns}$ \\
ANOVA & $*$ & $*$ & . \\
\hline
\end{tabular}

irrigations: ns (no significant difference). varieties: *(significant difference at $\mathrm{p}<0.05)$. interactions irrigations $\mathrm{x}$ varieties: $\mathrm{ns}$.

Table 3. Durations and start and end dates of the development phases for the varieties 'Achefri', 'Aissa' and 'Moussa' under T1, T2 and T3 treatments of irrigation, year 2012.

\begin{tabular}{|c|c|c|c|c|c|c|}
\hline & \multicolumn{2}{|c|}{$\begin{array}{l}\text { Phase of the formation of } \\
\text { floral buds }\end{array}$} & \multicolumn{2}{|c|}{ Phase of flowering } & \multicolumn{2}{|c|}{ Phase of fruit maturation } \\
\hline & $\begin{array}{c}\text { Duration } \\
\text { (days) }\end{array}$ & $\begin{array}{c}\text { Start and end } \\
\text { dates }\end{array}$ & $\begin{array}{c}\text { Duration } \\
\text { (days) }\end{array}$ & $\begin{array}{c}\text { Start and end } \\
\text { dates }\end{array}$ & $\begin{array}{c}\text { Duration } \\
\text { (days) }\end{array}$ & $\begin{array}{c}\text { Start and end } \\
\text { dates }\end{array}$ \\
\hline \multicolumn{7}{|c|}{ 'Aïssa' } \\
\hline $\mathrm{T} 1(0 \mathrm{~mm})$ & 98 & $02 / 02-09 / 05$ & 85 & $27 / 03-20 / 06$ & 76 & $22 / 06-06 / 09$ \\
\hline $\mathrm{T} 2(60+60 \mathrm{~mm})$ & 98 & $02 / 02-09 / 05$ & 99 & $20 / 03-27 / 06$ & 91 & $14 / 06-13 / 09$ \\
\hline $\mathrm{T} 3(0+60 \mathrm{~mm})$ & 98 & $02 / 02-09 / 05$ & 99 & $20 / 03-27 / 06$ & 91 & $14 / 06-13 / 09$ \\
\hline \multicolumn{7}{|c|}{ 'Moussa' } \\
\hline $\mathrm{T} 1(0 \mathrm{~mm})$ & 83 & $02 / 02-24 / 04$ & 78 & $27 / 03-13 / 06$ & 84 & $14 / 06-06 / 09$ \\
\hline $\mathrm{T} 2(60+60 \mathrm{~mm})$ & 92 & $02 / 02-02 / 05$ & 92 & $20 / 03-20 / 06$ & 84 & $14 / 06-06 / 09$ \\
\hline $\mathrm{T} 3(0+60 \mathrm{~mm})$ & 92 & $02 / 02-02 / 05$ & 92 & $20 / 03-20 / 06$ & 84 & $14 / 06-06 / 09$ \\
\hline \multicolumn{7}{|c|}{ 'Achefri' } \\
\hline $\mathrm{T} 1(0 \mathrm{~mm})$ & 76 & $10 / 02-24 / 04$ & 70 & $27 / 03-06 / 06$ & 61 & $22 / 06-22 / 08$ \\
\hline $\mathrm{T} 2(60+60 \mathrm{~mm})$ & 83 & $10 / 02-02 / 05$ & 77 & $27 / 03-13 / 06$ & 76 & $14 / 06-29 / 08$ \\
\hline $\mathrm{T} 3(0+60 \mathrm{~mm})$ & 76 & $10 / 02-24 / 04$ & 77 & $27 / 03-13 / 06$ & 68 & $22 / 06-29 / 08$ \\
\hline
\end{tabular}


than 7 buds/cladode in some varieties whereas it did not exceed 5 buds/cladode in not irrigated treatments of the all varieties) (as shown in Table 4). Irrigation has favored the emission of vegetative and floral buds. Several authors also confirmed that irrigation increases the emission and formation of the organs in the plant, in particular the vegetative and floral buds (Mulas and D'Hallewin, 1997; Inglese, 2010; Nerd and Mizrahi, 2010).

Irrigation had significant positive effects on the duration of the flowering phase of all three varieties: for 'Aissa', 99 days long in irrigated treatments $v s$ only 85 days in not irrigated treatment; for 'Moussa', 92 days long in irrigated plants vs 78 days in not irrigated plants; and for 'Achefri', 77 days long vs 70 days in not irrigated plants (as shown in Table 3). The flowering peak in all varieties and treatments of irrigation is located between the end of April and the first fortnight of May. Irrigation also has had an effect on the number of flowered buds (more than 6 flowered buds/cladode in irrigated treatments and not more than 5 flowered buds/cladode in not irrigated treatments). Several authors also reported that irrigation increases the emission of floral buds in cactus pear (Mulas and D'Hallewin, 1997; Nerd and Mizrahi, 2010).

The duration of the fruit maturation phase was longer for irrigated treatments of 'Aissa' (91 days in T2 and T3 $v s$ only 76 days in T1 not irrigated) and 'Achefri' (76 days in T2 and 68 in T3 vs 61 days in T1). For 'Moussa', irrigations have had no effect on the duration of the maturation phase (as shown in Table 3 ). The maturation peak for all varieties and treatments of irrigation is located in the $1^{\text {st }}$ week of August.

For all the varieties, the date of July $31^{\text {st }}$ can be considered as the date of $50 \%$ of fruit maturation. The FDP of all varieties and treatments of irrigation varies between 172 and 180 days. It's as long as the FDP reported for other varieties in South Africa or Italy, including those which have an earlier emission of floral buds (Barbara, 2007; Nerd and Mizrahi, 2010).

In this second year overlapping between two successive phases has been observed. For 'Aïssa' and 'Moussa', the phases of flowering and fruit ripening overlap each other for one to two weeks; but for 'Achefri' they are quite distinct, without overlapping.

Irrigations T2 and T3 have had little effect on the durations of the floral buds formation: no effect on 'Aissa' and one week prolongation on 'Moussa' and 'Achefri'. They have induced a slight increase on the flowering phase duration, 7 days at 'Achefri' and 14 days ( 7 days precocity and 7 days lateness) at 'Aissa' and 'Moussa'. Irrigations also have prolonged the duration of the fruit maturation phase for two weeks in 'Aissa' and one to two weeks for 'Achefri' but they have had no effect on this duration on 'Moussa'. These prolongations concern only a very low proportion of flowers or matured fruits

From the maturation dynamics described by the counted numbers of ripe fruits at the seven observations made from June to September, it can be considered that the 4 weeks period located between July $17^{\text {th }}$ and August $15^{\text {th }}$ was that of the full harvest (indicated by (B) in Table 5), harvests before

Table 4. Emission of vegetative and floral buds and of shoots at the three varieties 'Achefri', 'Aissa' and 'Moussa' under the three treatments of irrigation T1, T2 and T3 in 2012.

\begin{tabular}{lccc}
\hline \multicolumn{1}{c}{$\begin{array}{c}\text { Treatments of } \\
\text { irrigation }\end{array}$} & Achefri & Varieties & Moussa \\
\cline { 2 - 4 } & Number of emitted buds by cladode in March & 2.67 \\
\hline T1 $(0 \mathrm{~mm})$ & $4.14 a$ & $3.12 a$ & 3.06 \\
T2 $(60+60 \mathrm{~mm})$ & $7.20 b$ & $3.94 a b$ & 2.80 \\
T3 $(0+60 \mathrm{~mm})$ & $4.24 a$ & $4.50 b$ & $\mathrm{~ns}$ \\
ANOVA & $*$ & $*$ & $0.08 a$ \\
\hline T1 $(0 \mathrm{~mm})$ & Number of emitted shoots by cladode & $0.35 c$ \\
T2 $(60+60 \mathrm{~mm})$ & $0.17 a$ & $0.10 a$ & $0.20 b$ \\
T3 $(0+60 \mathrm{~mm})$ & $0.50 b$ & $0.25 b$ & $*$ \\
ANOVA & $0.20 a$ & $0.15 a$ & $*$ \\
\hline
\end{tabular}

ns: no significant difference. *significant differences between irrigations at $\mathrm{p}<0.05$.

Table 5. Maturation dynamics in 2012 season, for the varieties 'Achefri', 'Aissa' and 'Moussa': (N) Total numbers of fruits per 10 cladodes; (A) proportions (in \%) of ripe fruits before July $17^{\text {th }} ;$ (B) between July $17^{\text {th }}$ and August $15^{\text {th }}$; (C) after August $15^{\text {th }}$.

\begin{tabular}{|c|c|c|c|c|c|c|c|c|c|c|c|c|}
\hline \multirow{2}{*}{ Traitement } & \multicolumn{4}{|c|}{ 'Moussa' } & \multicolumn{4}{|c|}{ 'Aissa' } & \multicolumn{4}{|c|}{ 'Achefri' } \\
\hline & $\mathbf{N}$ & A (\%) & B (\%) & $\overline{C(\%)}$ & $\mathbf{N}$ & $A(\%)$ & B (\%) & $\mathrm{C}(\%)$ & $\mathbf{N}$ & $A(\%)$ & B (\%) & $\mathrm{C}(\%)$ \\
\hline T1 $0+0$ & 75 & 23.0 & 64.7 & 12.3 & 75 & 19.9 & 58.5 & 21.6 & 76 & 16.4 & 78.3 & 5.3 \\
\hline $\mathrm{T} 260+60$ & 92 & 24.3 & 64.3 & 11.4 & 95 & 21.3 & 59.2 & 19.2 & 100 & 20.4 & 72.1 & 7.5 \\
\hline $\mathrm{T} 30+60$ & 87 & 23.2 & 64.2 & 12.6 & 93 & 21.4 & 58.4 & 20.0 & 82 & 16.2 & 78.7 & 5.2 \\
\hline
\end{tabular}


July $17^{\text {th }}$ (A) and after August $15^{\text {th }}$ (C) can be considered as "early" and "late" harvests for marketing. For each irrigation treatment, the number of ripe fruits during each period A, B and C, has been expressed as a percentage of the total number of produced fruits (as shown in Table 5). Results showed at first that whatever the treatment of irrigation, the harvest in period B represents about $58 \%$ of fruits in 'Aissa' and 64\% in 'Moussa'. Applied treatments of irrigation did not modify the proportions of fruits maturing during the early period (A) or the late period (C) ( $23 \%$ of early fruits and $12 \%$ of late fruits in 'Moussa', and respectively $21 \%$ and $20 \%$ in 'Aissa' variety). For 'Achefri', T2 treatment which caused a prolongation of the maturation period, involve a significant increase of a period of one week in the earlier proportion of fruits $(+4 \%)$ and a late percentage of fruits $(+2 \%)$. These differences are weak and not of a sufficient economic interest.

In the second year experiments, irrigation favored the emission of growths. The number of emitted shoots per cladode was higher in irrigated treatments of the all varieties ( $0.15-0.50$ growths/cladode) than in not irrigated treatment of these varieties (0.075-0.10 growths/cladode) (as shown in Table 4). It is also important to note that the emission of growths is more important in two years and older cladodes than in one year old cladodes. For 'Achefri' for example, in the second year experiments, the emission of growths in two years and older cladodes of irrigated treatments was $0.75-1.0$ growths/cladode $v s$ 0.35-0.5 in one year old cladodes of these treatments. In the first year experiments, irrigation did not modify the emission of shoots between irrigation treatments of all varieties because irrigation coincided with rains in March-May when the emission of shoots is important in these varieties.

\section{Conclusions}

In the first year experiments, the effect of irrigations on the phenology of flowering and fruiting of the three varieties was negligible because irrigations coincided with rains in March-May. The only positive effect of irrigation appeared on flowering and the duration of flowering of the thorny variety 'Achefri'. In the second year experiments, irrigations had a positive effect on the emission of buds (as shown in Table 4) and on flowering of the three varieties.

The applied irrigations doses during the two years of trials ( 30 to $120 \mathrm{~mm}$ ) have little modified the lengths of the development phases, generally for few days. We know in addition that these irrigations increased the yields, by increasing amongst other things the number of fruits (Arba et al., 2016). This higher number of fruits becomes ripe during the same periods in proportions which are not significantly modified by application of irrigation water. We can thus conclude that, under our conditions irrigation has not allowed to significantly elongate the fruit maturation periods, neither in precocity, nor in lateness. Irrigation did not let appear eventual possibilities of better commercial valorization by a shift of the fruits maturation dates.
The beneficial effect of irrigation on the emission of shoots has been demonstrated. Several authors also reported that irrigation increases the emission of the organs (buds, flowers, growths) in cactus pear (Mulas and D'Hallewin, 1997; Inglese, 2010; Nerd and Mizrahi, 2010). In dry periods irrigation seems to increase the growth emission both on one year and on older cladodes.

\section{Acknowledgements}

The authors wish to thank the Belgian Technical Cooperation (BTC) and Agrotech Souss Massa Draa for their financial support, and to all the people who contributed to the realization of this study.

\section{References}

ARBA, M., 2009. Le cactus opuntia une espèce fruitière et fourragère pour une agriculture durable au Maroc. In: A. BOUAZIZ, R. CHOUKR-ALLAH, R. MRABET and A. FALISSE, eds. Actes $d u$ Symposium International AGDUMED - durabilité des systèmes de culture en zone méditerranéenne et gestion des ressources en eau et en sol, 14-16 Mai 2009, Rabat. Rabat: Cana Print, pp. 215-223.

ARBA, M., FALISSE, A., CHOUKR-ALLAH, R., SINDIC, M., 2016. Effects of irrigation at critical crop stages on fruit yield and quality of cactus pear (opuntia spp.). Scientific Journal of Crop Science, vol. 5, no. 3, p. 73-81. http://dx.doi.org/10.14196/ sjcs.v5i3.2150.

BARBARA, K.M., 2007. Characterization of cactus pear germplasm in South Africa. South Africa: Faculty of Natural and Agricultural Sciences, University of the Free State, 194 p. Thesis of Philosophiae Doctor.

DUBEUX JUNIOR, J.C.B., SANTOS, M.V.F., LIRA, M.A., SANTOS, D.C., FARIAS, I., LIMA, L.E. and FERREIRA, R.L.C., 2006. Productivity of Opuntia ficus-indica (L.) Miller under different $\mathrm{N}$ and $\mathrm{P}$ fertilization and plant population in north-east Brazil. Journal of Arid Environments, vol. 67, no. 3, pp. 357-372. http://dx.doi.org/10.1016/j.jaridenv.2006.02.015.

FELKER, P. and INGLESE, P., 2003. Short-term and long-term research needs for Opuntia ficus-indica (L.) Mill. utilization in arid areas. Journal of the Professional Association for Cactus Development, vol. 7, pp. 131-152.

FOOD AND AGRICULTURE ORGANIZATION OF THE UNITED NATIONS - FAO, 2013. Agro-industrial utilization of cactus pear. Rome: Rural Infrastructure and Agro Industrial Division, $150 \mathrm{p}$.

INGLESE, P., 2010. Cactus pear Opuntia ficus-indica (L.) Mill. for fruit production: an overview. Rome: FAO. Cactusnet Newsletter Special Issue.

LE HOUÉROU, H.N., 2002. Cacti (Opuntia spp.) as a fodder crop for marginal lands in the Mediterranean basin. Acta Horticulturae, no. 581, pp. 21-46. http://dx.doi.org/10.17660/ ActaHortic.2002.581.1.

LENZI, M. and ORTH, A.I., 2012. Mixed reproduction systems in Opuntia monacantha (Cactaceae) in Southern Brasil. Brazilian Journal of Botany, vol. 35, no. 2, pp. 49-58. http://dx.doi. org/10.1590/S1806-99592012000100006. 
MULAS, M. and D'HALLEWIN, G., 1997. Fruit quality of four cactus pear (Opuntia ficus-indica Mill.) cultivars as influenced by irrigation. Acta Horticulturae, no. 438, pp. 115-122. http:// dx.doi.org/10.17660/ActaHortic.1997.438.14.

NEFZAOUI, A. and BENSALEM, H., 2000. Opuntia: a strategic fodder and efficient tool to combat desertification in the WANA region. Rome: FAO. Cactusnet Newsletter Special Issue.

NERD, A. and MIZRAHI, Y., 2010. Reproductive biology of cactus fruit crops. Horticultural Reviews, vol. 18, pp. 321-346.

NOBEL, P.S. and BOBICH, E.G., 2002. Environmental biology. In: P.S. Nobel, ed. Cacti: biology and uses. Berkeley: University of California Press, pp. 57-74.

NOBEL, P.S., 2002. Cacti: biology and uses. California: University of California Press, 291 p.

OLIVEIRA, V.S., FERREIRA, M.A., GUIM, A., MODESTO, E.C., LIMA, L.E. and SILVA, F.M., 2007. Total replacement of corn and partial of tifton hay by forage cactus in diets for lactating dairy cows. Intake and digestibility. Revista Brasileira Zootecnia, vol. 36, no. 5, pp. 1419-1425.

PIMIENTA-BARRIOS, E. and DEL CASTILLO, R.F., 2002. Reproductive biology. In: P.S. Nobel, ed. Cacti: biology and uses. Berkeley: University of California Press, pp. 75-90.

RAMOS, J.P.F., SANTOS, E.M., CRUZ, G.R.B., PINHO, R.M.A. and FREITAS, P.M. D., 2015. Effects of harvest management and manure levels on cactus pear productivity. Revista Caatinga, vol. 28, no. 2, pp. 135-142.

REYES-AGÜERO, J.A., AGUIRRE R, J.R. and RODRIGUEZFLORES, J.L., 2005. Variacion morfologica de Opuntia (Cactaceae) en relacion con sa domesticacion en la Altiplanicie Meridional de Mexico. Intersciencia, vol. 30, no. 8, pp. 476-484.

REYES-AGÜERO, J.A., AGUIRRE R, J.R. and VALIENTEBANUET, A., 2006. Reproductive biology of Opuntia: a review. Journal of Arid Environments, vol. 64, no. 4, pp. 549-585. http:// dx.doi.org/10.1016/j.jaridenv.2005.06.018.

SALES, T.A., ANDRADE, P.A., SILVA, S.D., LEITE, M.L.M.V., VIANA, L.B., LEÓN, M.J. and SOLÍS, A.M., 2009. Adaptation potential of cactus pear to soil and climatic conditions of the semi arid in Paraíba State, Brazil. Acta Horticulturae, no. 811, pp. 395-400. http://dx.doi.org/10.17660/ActaHortic.2009.811.54.

SEGANTINI, D. M.; TORRES, L. A.; BOLIANI, A. C.; LEONEL, S. Phenology of cactus pear in Selviria-MS State, Brazil. Brazilian Journal of Horticulture, v. 32, n. 2, p. 630-636, 2010.

SILVA, T.G.F., PRIMO, J.T.A., SILVA, S.M.S., MOURA, M.S.B., SANTOS, D.C., SILVA, M.C. and ARAÚJO, J.E.M., 2014. Indicadores de eficiência do uso da água e de nutrientes de clones de palma forrageira em condições de sequeiro no Semiárido brasileiro. Bragantia, vol. 73, no. 2, pp. 184-191. http://dx.doi. org/10.1590/brag.2014.017 